\title{
Effect of labor and number of micro and small enterprises (MSEs) on poverty rate in Indonesia
}

\author{
Siti Hodijah; Candra Mustika* \\ Development Economics Department, Faculty of Economics and Business, Universitas \\ Jambi, Indonesia
}

*To whom correspondence should be addressed.Email: candra.mustika@yahoo.com.

\begin{tabular}{|l|l|l|l|l|}
\hline DOI: & Received: & Revised: & Accepted: & Published: \\
10.22437/ppd.v8i3.9076 & 16.04 .2019 & 04.06 .2020 & 07.08 .2020 & 31.08 .2020 \\
\hline
\end{tabular}

\begin{abstract}
The study aims to analyze the poverty and micro and small enterprises in 34 provinces in Indonesia, and to analyze the effect of labor and the number of micro and small enterprises on poverty levels in Indonesia. The results indicate that Papua Province has the highest poverty rate and the DKI Jakarta Province has the lowest poverty rate. Central Java Province has the largest number of micro-enterprises, and West Papua Province has the lowest number of micro-enterprises. For small enterprises, Central Java Province has the highest number and West Papua Province has the lowest number. Meanwhile, Central Java Province as the largest number of micro-business workers, and West Papua Province has the lowest number workers. For small business workers, Central Java Province has the largest number and West Papua Province has the lowest number. The results of panel data regression show that some variables, such as smallenterprise worker and the number of micro enterprises, have a significantly negative effect on the poverty rate. On the other hand, micro-enterprise worker and the number of small enterprises have a positive and significant effect on poverty rate.
\end{abstract}

Keyword: Poverty, Labor, Micro and small enterprises

JEL Classification: O14, I32, J21, J24

\section{INTRODUCTION}

Development and poverty are like two sides of a coin, and both go together in an attempt to improve or as part of underdevelopment and inability to meet the basic needs of life. The structural approach to poverty suggests that there are shortcomings in the geographical, ecological, technological, and demographic aspects that still require efforts to empower them, especially for the food needs. Many previous studies on the determinants of poverty and well-being have been conducted. Empirical findings, however, continue to generate controversy among researchers (Hardiwan, Amir, Junaidi \& Delis, 2019) and there is no profound empirical answer by looking at the exact factors that could influence poverty and household welfare.

At the national level, the poverty rate had decreased in Indonesia since the beginning of the New Order era. It went from about 40\% in 1970 to $17.5 \%$ in 1996. However, after the Asian monetary crisis of 1997-1998, the poverty rate (due to the forced closure of a large number of industries/companies and reduced production 
volume) increased to $24.2 \%$ in 1998 . Then it started to decline every year and was recorded at $12.5 \%$ in 2011 . However, the poverty rates vary between provinces and many provinces have it far above the national average. In 2010, the national poverty rate was $13.3 \%$ and in the same year there were 16 provinces with poverty rates above the national level. Papua has turned to be the poorest province, and DKI Jakarta has the lowest rate of about $4 \%$.

There are several causes that contribute to poverty, as well as the poverty rate difference between provinces. This is partly due to differences in the determinants of poverty, particularly job opportunities in the formal sector. Regions with high rate of open unemployment are typically considered poor areas. The number of open unemployment is known to be the key factor, but not the only factor determining the cause of poverty. Poverty in a region can be very noticeable, although the number of people with non-permanent jobs in the formal sector is very limited. In general, poverty in this case is caused by low income or low real wage of workers that is below the minimum wage of the regency/city. There are many villages in Indonesia whose economic activities are generally in micro or small scale in the informal sector with very low incomes.

Theoretically, the relationship between Micro and Small Enterprises (MSEs) and poverty in a region have two possibilities, respectively "positive" and "negative". This is a positive relationship as MSEs exist due to poverty. In general, a business emerges when there are demand markets, both the output market (goods and services) for selling products and input market (labors) for receiving inputs for production. This relationship also applies to the growth of MSEs. However, in many developing/poor countries, the presence of output and input markets that grow rapidly the number of MSEs is closely related to poverty.

In his research on micro and small-sized enterprises (MSEs) and poverty, Tambunan (2012) explored the role of MSEs in poverty alleviation in the region. The findings of this study indicate that MSEs are indeed important for the reduction of poverty in the region (province). However, its role varies between provinces, as gaps in MSEs' access to essential inputs such as education, technical assistance, raw materials, and capital are found. Even then, an in-depth study is required to examine the role of SMEs in poverty alleviation.

Several studies have found the relationship between poverty reduction, economic growth, and micro-enterprise development. Research by Mduduzi Biyase \& Talent Zwane, revealed the determinants of poverty and household welfare in South Africa. Contrary to most existing studies that applied ordinary least squares (OLS) and probit and logit models to cross-sectional data, this study found the unobserved individual heterogeneity and endogeneity, in which both are viafix and through robust alternative based on random-effects probit model. The results of fixed and random effects show that the educational attainment of the head of the household, the race of the head of the household, the dependency ratio, the gender of the head of the household, working status of the head of the household, and the marital status of the head of the household are statistically significant determinants of household welfare.

The results of Jasin, Saud, Isa, \& Hussain's study (2016) suggest that the bureaucratic procedures have no meaningful relationship with micro-enterprises' performance. However, facilities have a significant effect on the micro-enterprises' performance. Haryadi \& Rosmeli (2018) examined the factors influencing the income of MSMEs in Jambi City. The findings indicate that labor have a positive effect on the development of MSMEs in Jambi City. According to Rahmini's study (2017), the success experienced by MSMEs has shortcomings that need to be fixed immediately, 
including lack of capital, lack of managerial skills, and limited operational and marketing skills encountered by all SMEs at the start of growing a business.

According to Machmud \& Sidharta (2013), the development of MSMEs in Bandung City can be carried out using a strategic approach. The first step is to determine factors impacting MSMEs and then to evaluate the strengths, weaknesses, opportunities, and threats of MSMEs. The next step is the formulation of MSME development concept as well as the goals and objectives. The implementation of MSME policies, MSME development programs, and MSME development activities may be carried out after the formulation of concept, goals, and objectives.

Danuar (2017) and Junaidi, Yulmardi \& Hardiani (2020 points out that the growth of MSMEs still faces a range of challenges in many regions. Research by Danuar (2017) findings in SMEs in Semarang indicate that SMEs in the creative sector have limited abilities and experience difficulties in expanding their business. This causes SMEs in the creative sector not to be able to provide Semarang with distinctive characteristics. The problems faced by SMEs in Semarang include capital, raw materials and production factors, labor, transaction costs, marketing, and IPR (Intellectual Property Rights). Harvie (2013) conducted a study to evaluate the contribution of microenterprises to economic recovery and poverty alleviation in East Asia.

Based on these, the study aims to analyze the poverty and micro and small enterprises in 34 provinces in Indonesia, and to analyze the effect of labor and the number of micro and small enterprises on poverty levels in Indonesia

\section{METHODS}

This study uses panel datasets of 34 provinces during 2013-2017 in Indonesia. The data were obtained from Statistics Indonesia. Analysis is carried out using multiregression analysis using panel data method. This approach can be used as a prediction model for a dependent variable from one independent variable using time series and cross-section data. The model is:

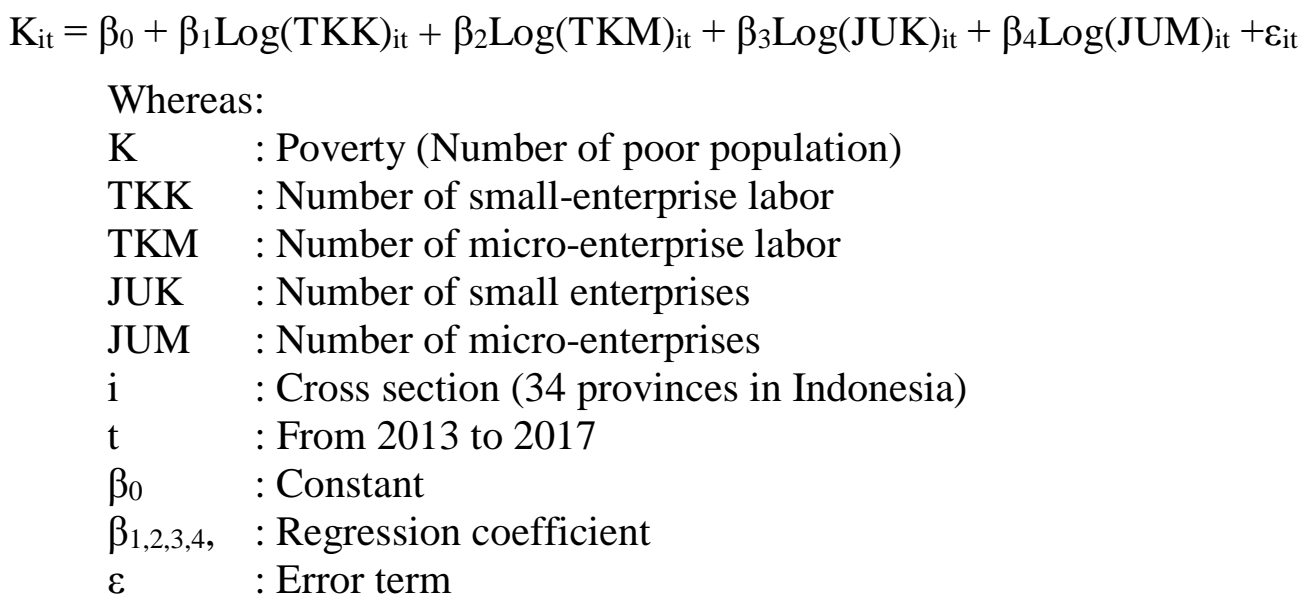

\section{RESULTS AND DISCUSSION}

\section{Poverty and micro and small enterprises in Indonesia}

Data are given to show the poverty condition (the number of poor population and poverty rate) and small enterprise condition (number of micro enterprises, number of small enterprises, micro-enterprise labor, and small-enterprise labor) in 34 provinces in Indonesia during the period 2013-2017. However, statistics on micro and small 
enterprises over the last two years (2016-2017) are predictive data. Details are provided in the Table 1.

Table 1. Poverty and MSEs in Indonesia

\begin{tabular}{|c|c|c|c|c|c|c|}
\hline Provinces & $\begin{array}{l}\text { Number of } \\
\text { poor } \\
\text { population }\end{array}$ & $\begin{array}{c}\text { Poverty } \\
\text { rate }\end{array}$ & $\begin{array}{c}\text { Number of } \\
\text { micro } \\
\text { enterprises }\end{array}$ & $\begin{array}{c}\text { Number of } \\
\text { small } \\
\text { enterprises }\end{array}$ & $\begin{array}{l}\text { Micro- } \\
\text { enterprise } \\
\text { labor }\end{array}$ & $\begin{array}{c}\text { Small- } \\
\text { enterprise } \\
\text { labor }\end{array}$ \\
\hline Aceh & 845 & 16.83 & 69,036 & 2,202 & 117,401 & 15,904 \\
\hline North Sumatera & 1,408 & 10.12 & 79,372 & 10,381 & 150,344 & 78,067 \\
\hline West Sumatera & 364 & 7.01 & 64,688 & 5,654 & 112,823 & 44,743 \\
\hline Riau & 516 & 8.06 & 15,477 & 1,235 & 30,818 & 8,389 \\
\hline Jambi & 289 & 8.44 & 23,541 & 2,062 & 45,353 & 13,970 \\
\hline South Sumatera & 1,098 & 13.59 & 54,393 & 6,694 & 101,762 & 52,190 \\
\hline Bengkulu & 318 & 16.92 & 11,229 & 803 & 22,943 & 5,617 \\
\hline Lampung & 1,120 & 13.81 & 86,981 & 7,874 & 182,652 & 61,859 \\
\hline Bangka Belitung Islands & 70 & 5.08 & 7,668 & 756 & 14,671 & 5,683 \\
\hline Riau Islands & 122 & 6.10 & 11,735 & 1,081 & 17,520 & 7,826 \\
\hline Dki Jakarta & 387 & 3.79 & 21,453 & 15,979 & 50,993 & 141,877 \\
\hline West Java & 4,210 & 8.99 & 416,345 & 72,982 & 824,217 & 596,023 \\
\hline Central Java & 4,493 & 13.35 & 792,823 & 103,598 & $1,507,783$ & 812,157 \\
\hline Di Yogyakarta & 502 & 13.64 & 64,348 & 8,136 & 113,296 & 68,205 \\
\hline East Java & 4,687 & 12.07 & 646,456 & 57,793 & $1,274,632$ & 474,030 \\
\hline Banten & 676 & 5.62 & 86,144 & 7,466 & 149,932 & 62,384 \\
\hline Bali & 191 & 4.56 & 96,386 & 12,114 & 163,516 & 98,313 \\
\hline West Nusa Tenggara & 791 & 16.38 & 88,724 & 12,158 & 159,764 & 131,979 \\
\hline East Nusa Tenggara & 1,089 & 21.16 & 93,476 & 2,596 & 159,014 & 20,543 \\
\hline West Kalimantan & 392 & 8.22 & 42,432 & 1,350 & 79,597 & 10,262 \\
\hline Central Kalimantan & 144 & 5.77 & 16,001 & 980 & 29,666 & 6,726 \\
\hline South Kalimantan & 188 & 4.70 & 62,375 & 3,015 & 101,443 & 24,122 \\
\hline East Kalimantan & 230 & 6.17 & 15,559 & 2,062 & 132,081 & 79,768 \\
\hline North Kalimantan & 50 & 7.75 & 2,545 & 358 & 23,767 & 14,516 \\
\hline North Sulawesi & 202 & 8.37 & 37,367 & 785 & 66,540 & 5,904 \\
\hline Central Sulawesi & 406 & 14.06 & 29,807 & 2,072 & 56,125 & 15,965 \\
\hline South Sulawesi & 830 & 9.74 & 103,194 & 6,375 & 187,934 & 53,661 \\
\hline Southeast Sulawesi & 325 & 13.00 & 57,335 & 3,705 & 107,982 & 25,978 \\
\hline Gorontalo & 201 & 17.67 & 18,516 & 1,145 & 32,810 & 8,207 \\
\hline West Sulawesi & 152 & 11.71 & 21,390 & 1,013 & 34,418 & 7,680 \\
\hline Maluku & 322 & 18.92 & 29,988 & 363 & 47,415 & 2,616 \\
\hline North Maluku & 80 & 6.82 & 7,665 & 108 & 11,768 & 832 \\
\hline West Papua & 224 & 25.43 & 2,138 & 100 & 3,976 & 721 \\
\hline Papua & 929 & 28.78 & 8,510 & 609 & 18,809 & 3,874 \\
\hline
\end{tabular}

Source: Statistics Indonesia (Processed Data)

As shown in Table 1, each variable has fluctuated in most provinces. The highest poverty rate is in Papua Province of $28.7 \%$ and the lowest poverty rate is in DKI Jakarta Province of $3.79 \%$. Central Java Province has the highest number of micro-enterprises, with 792,822 units, and West Papua Province has the lowest number of 2,138 units. Central Java Province also has the highest number of small enterprises with 103,598 units, while West Papua has the lowest number of only 100 units.

The province with the largest number of micro-business workers is Central Java Province with 1,507,782 people and West Papua Province has the lowest number with 3,975 people. For small-enterprise workers, Central Java also has the largest number, with 812,157 people, and West Papua Province has the lowest number, with 720 people. 


\section{Influence of the number of micro and small enterprises and micro and small labor on poverty rates in Indonesia}

To determine the effect of the number of micro and small enterprises, and small and micro enterprise labor on poverty rates in Indonesia, this study used multiregression panel data with a semi-log model based (which produce three panel data models: Common Effect, Fixed Effect and Random Effect). To choose the best panel data regression model from the three models, three testing methods are used (Chow Test, Hausman Test and LM Test) (see appendix). Based on the results of the three tests and the results of the regression output, it is concluded that Common Effect is the best model. Panel data regression with common effect can be seen in Table 2.

Table 2. Results of panel data regression with Common Effect

\begin{tabular}{ccccc}
\hline Variable & Coefficient & Std. Error & t-Statistics & Prob. \\
\hline C & 26.16187 & 5.673888 & 4.610925 & 0.0000 \\
LOG (TKK?) & $-11,63971$ & 3.063066 & -3.800021 & 0.0002 \\
LOG (TKM?) & 10,06482 & 3,289888 & 3.059320 & 0.0026 \\
LOG (JUK?) & 10,20360 & 3.025126 & 3.372949 & 0,0009 \\
LOG (JUM?) & -8.702513 & 3.086611 & -2.819440 & 0.0054 \\
\hline R-squared & 0.129765 & Mean dependent var & 11,54812 \\
Adjusted R-squared & 0.108668 & SD dependent var & 6.033314 \\
SE of regression & 5.696074 & Akaike info criterion & 6,346402 \\
Sum squared resid & 5353,468 & Schwarz criterion & 6.438631 \\
Log likelihood & $-534,444$ & Hannan-Quinn criter. & 6.383828 \\
F-statistics & 6.150977 & Durbin-Watson stat & 0.120779 \\
Prob (F-statistic) & 0,000123 & & \\
\hline
\end{tabular}

Based on the results of panel data regression, it indicates that small enterprise labor and the number of micro-enterprises have a negative and significant effect on the poverty rate. This signifies that increasing the labor absorption by small enterprises will reduce the poverty rate. However, an increase in the number of small enterprises will raise the poverty level. Thus, the opposite effect on poverty is between labor and the number of small enterprises. This phenomenon shows that developing existing small businesses is better than adding business units because, in order to increase goods production, they will employ more workers. Absorption of small enterprise workers has a negative effect on poverty.

In the case of micro-enterprises, it also has an inverse correlation between the number of enterprises and the labor. The number of micro-enterprises has a negative impact on poverty, while the labor affects poverty rate positively. This assumes that adding micro-enterprise units will minimize the poverty rate, and adding more labor will raise the poverty rate. The growth of micro-enterprises should be continued by increasing the number of business units without raising the number of employees. This is presumably because the wage or income earned by micro-enterprise workers is smaller than that received by employees in small enterprises.

Based on the results of the analysis, it has been found that small enterprises and micro-enterprises, both in terms of number of businesses and their labor force, have a substantial effect on the poverty rate. Ideally, all four independent variables have a negative influence on the poverty rate. However, there are only two variables that have a negative impact on the poverty rate. The findings of this study show that the number of small enterprises should not be expanded, but that the output of existing small enterprises should be produced on a larger scale. The greater volume of production would absorb more labor force. In the case of small enterprises, labor has a negative effect on poverty. Meanwhile, for micro-enterprises, it is necessary to increase the 
number of business units without raising the number of employees. Labor in microenterprises has a positive impact on the poverty rate.

Several empirical studies on MSMEs on poverty and other economic indicators, such as Dartanto \& Nurkholis (2013), have shown that the provision of micro-credit has a significant effect on poverty. Supriyadi and Kausar (2016) also found that SMEs are contributing to the economy and development in Indonesia. Other study similar to this study, Tareq \& Rahman (2020) has argued that rural micro-enterprises play a significant role in reducing poverty. Our results indicate that policies should support the development of new micro-enterprises and expand existing enterprises that will help to alleviate poverty. Sarker \& Gazi (2013) have demonstrated a connection between poverty reduction and micro-enterprises in Bangladesh.

\section{CONCLUSION AND RECOMMENDATIONS}

\section{Conclusion}

The highest poverty rate is in Papua Province with $28.7 \%$ and the lowest poverty rate is in DKI Jakarta Province with $3.79 \%$. For the number of micro enterprises, Central Java Province has the largest number with 792,822 units, and West Papua Province has the lowest number with 2,138 units. For small enterprise, Central Java Province also has the largest number with 103,598 units, and West Papua has the lowest number with only 100 units. Province with the highest number of micro-business workers is Central Java Province with 1,507,782 people and West Papua Province has the lowest number with 3,975 people. For small enterprise workers, Central Java also has the largest number with 812,157 people and West Papua Province has the lowest number with 720 people.

The results of panel data regression with common effect model indicate that small enterprise labor and the number of micro-enterprises have a significant negative effect on poverty level, while micro-enterprise labor and the number of small enterprises have a positive and significant effect on poverty level.

\section{Recommendations}

For practitioners, current poverty alleviation programs must first be pursued and expanded, especially in regions with a high poverty rate. Second, existing small enterprises need to be developed without raising the number of units, but by growing the size of production so that they can accommodate the maximum workforce and help reducing poverty rate. Third, the development of micro enterprises has to be achieved by continuing to expand the number of business units without the recruitment of more employees in order to alleviate poverty.

For researchers, this study limited the research period to only five years. Further studies, therefore, should expand the research period and incorporate more variables.

\section{REFERENCES}

Biyase, M., \& Zwane, T. (2018). An Empirical Analysis of the Determinants of Poverty and Household Welfare in South Africa. Journal of Developing Areas, 52(1), 115-130.

Danuar, D. (2013). Development of Micro, Small and Medium Enterprises (MSMEs) Based on Creative Economy in the City of Semarang. Diponegoro Economic Journal, 2(4), . 1-13

Dartanto, T., \& Nurkholis. (2013). The determinants of poverty dynamics in Indonesia: evidence from panel data. Bulletin of Indonesian Economic Studies, 49(1), 61. 
Hardiwan, D., Amir, A., Junaidi, J. \& Delis, A. (2019). The linkages and impact of plantation-based sectors on economy and poverty in Jambi province, Indonesia: Miyazawa's input-output model. Agricultural and Resource Economics: International Scientific E-Journal, 5(3), 5-19

Haryadi \& Rosmeli (2018) Model of one Village one Product development with triple helix approach in improving the role of micro small and medium enterprises in Jambi city Indonesia. International Journal of Business, Economics and Law, 17(3), 49-57

Harvie, C. (2003). The Contribution of Microenterprisesto Economic Recovery and Poverty Alleviation in East Asia, Working paper no. 03-07, Department of Economics, University of Wollongong, Australia.

Jasin, H., Saud, M.B, Isa, M.A.M \& Hussain, F. (2016) Facilities and bureaucratic process of Malaysian local authorities influenced on micro enterprises business performance. International Journal of Business, Economics and Law, 10(2), 1420

Junaidi, J., Yulmardi, Y. \& Hardiani, H. (2020). Food crops-based and horticulturebased villages potential as growth center villages in Jambi Province, Indonesia. International Journal of Advanced Science and Technology, 29(3), 6118 - 6133

Rahmini, Y. (2017). Development of MSMEs (Micro, Small and Medium Enterprises) in Indonesia. CanoEconomics Scientific Journal, 6(1).

Sarker, M.M.H. \& Gazi, M.A.I. (2013). Poverty Reduction and Microenterprise in Bangladesh: Issues, Imperatives and Interventions, ASA University Review, 7(2), 169-182.

Supriyadi, E. \& Kausar, D.R.K. (2016). Impact of Inflation and Exchange Rate Rupiah toward Poverty and Unemployment in Indonesia (Case Study: Small Industry in the Tourist Area of Lombok). Journal of EST (Educational Science And Technology), 2(3), 204-212

Tambunan, T.T.H. (2012). Peran Usaha Mikro dan Kecil dalam Pengentasan Kemiskinan di Daerah. Jurnal Bina Praja, 4(2), 73 - 92

Tareq, M., \& Rahman, M. A. (2020). Foster, Greer and Thorbecke Class of Poverty Measures to Assess the Role of Rural Microenterprises in Poverty Reduction in Bangladesh. Journal of Developing Areas, 54(1), 89-103.

\section{APPENDIX}

Table 3. Chow Test (Common Efect vs Fixed Effect)

\begin{tabular}{lccc}
\hline $\begin{array}{l}\text { Redundant Fixed Effects Tests } \\
\text { Pool: POOL } \\
\text { Test cross-section fixed effects }\end{array}$ & & & \\
\hline Effects Test & Statistics & df & Prob. \\
\hline Cross-section F & 319.873412 & $(33,132)$ & 0.0000 \\
Chi-square cross-section & 746.989924 & 33 & 0.0000 \\
\hline
\end{tabular}

H0 : Common effect

H1 : Fixed effect

Probability is $0.000<5 \%$, so $\mathrm{H} 0$ is rejected and fixed effect model is accepted. 
Table 4. Hausman Test (Fixed Effect vs Random Effect)

Correlated Random Effects - Hausman Test

Pool: POOL

Random effects cross-section test

\begin{tabular}{lccc}
\hline Summary Test & $\begin{array}{c}\text { Chi-Sq. } \\
\text { Statistics }\end{array}$ & Chi-Sq. df & Prob. \\
\hline Random cross section & 7.091088 & 4 & 0.1312 \\
\hline
\end{tabular}

H0 : Random effect

H1 : Fixed effect

Probability is $0.1312>5 \%$, so $\mathrm{H} 0$ is accepted and $\mathrm{H} 1$ is accepted. Thus, the best model is Random Effect.

Table 5. Lagrange Multiplier Test (Random Effect vs Common Effect)

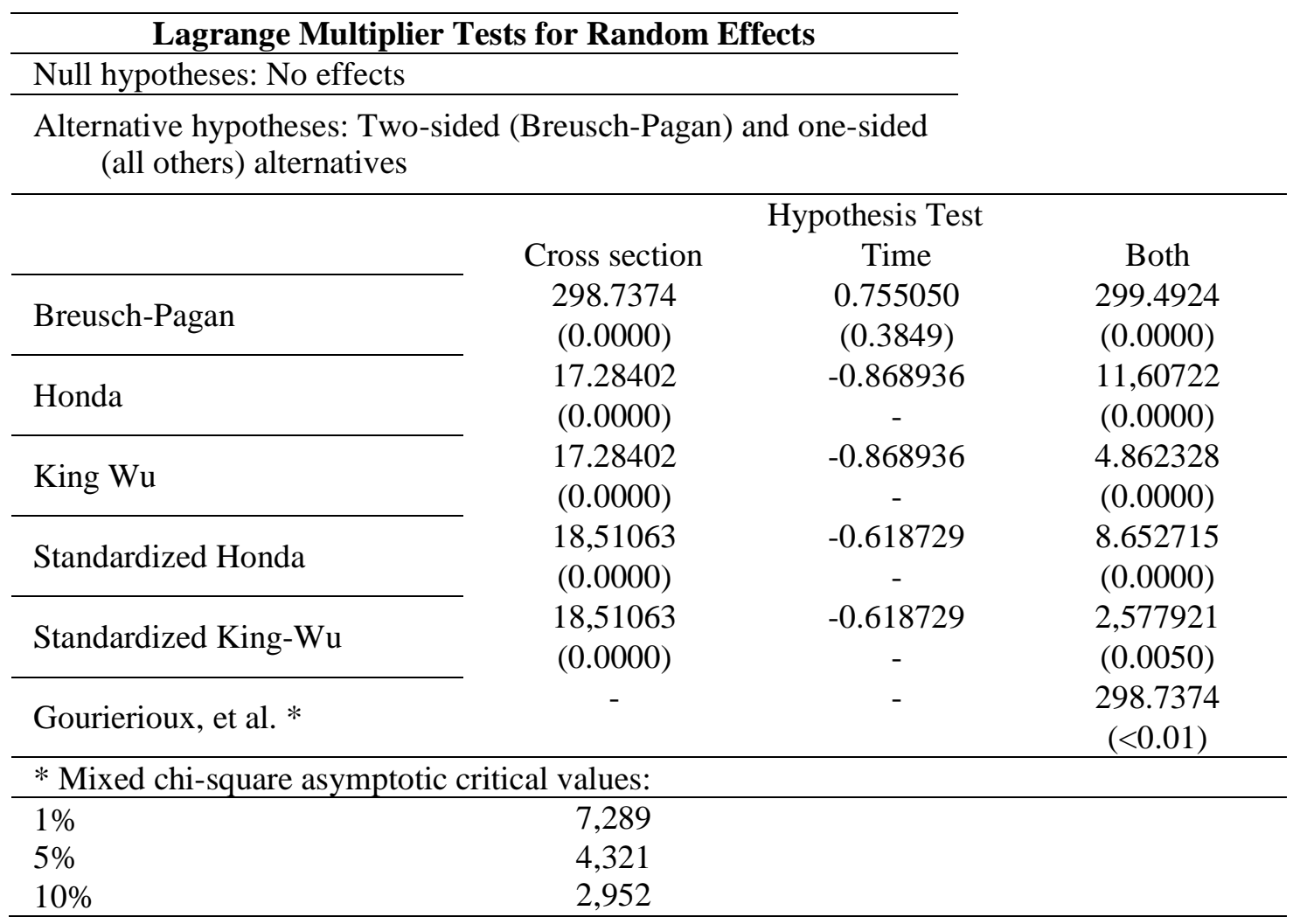

